The burden of history in the family business organization

(Published in Organization Studies, 37(8): 1089-1111, 2016

By

Daniel Hjorth, Copenhagen Business School (Denmark), and Nottingham Business

School, Nottingham Trent University (UK), and

Alexandra Dawson, Concordia University, Canada

\begin{abstract}
In this paper we focus on the study of history through the use of narratives, within the context of the prevalent form of organization worldwide: the family business. Specifically we consider the dilemma of the impossible gift of succession using Nietzsche's discussion of the burden of history and paralleling the story of a family business succession with that of Shakespeare's King Lear. This way, we seek to make a contribution to organizational studies by answering recent calls to engage more with history in studies of business organizations. By implication, the study also initiates an integration of family business studies into organization studies.
\end{abstract}

Keywords: History, narratives, Nietzsche, family business, succession 


\section{The burden of history in the family business organization}

\section{Introduction and framing}

There have been recent calls for organization studies (OS) scholars to engage more - and differently - with history (Clark \& Rowlinson, 2004; Rowlinson, Booth, Clark, Delahaye, \& Procter, 2010; Rowlinson \& Procter, 1999). Some have referred to this as indicating a 'historic turn' (Clark \& Rowlinson, 2004; Keulen \& Kroeze, 2012) that includes humanities and social sciences more broadly (Gallagher and Greenblatt, 2000; McDonald, 1996; Sahlins, 2004). Indeed, several recent theoretical advances - such as resource dependence theory, new institutionalism, and governmentality studies - are also more historically oriented in their conceptualization of organizational problems. This could be seen in the context of the emergence of a new historicism (Gallagher \& Greenblatt, 2000) that is as much a counterhistory - a practice of producing blows against 'grand récits' but also to emphasize the daily, quotidian, or mundane (de Certeau, 1984) - as it is history from below (central in postcolonial and feminist research; Butler, 1988; Spivak, 1990).

Our ambition to analyse inheritance in family business (FB) organizations will include sensitizing us to how history has a grip on self-making and agency in the transfer of the organization to the next generation. However, to move beyond a more traditional analysis of this as simply a battle between parents and children (Lee, 2006) we include reflections on the theoretical implications of how we frame history in OS. Nietzsche's problematization of history is key to our framing, and we will therefore elaborate on what follows from a Nietzschean understanding of history. Nietzsche opens up to analyses that makes change as he 'import[s] the creative act within the writing of history' (Söder, 2003, p. 75). This became a central discussion when the status of narrative was focused on history as discipline (White, 1973). We will use a narrative analysis of two cases of FB transitions and we will argue that a 
Nietzschean understanding of history is also 'powering up' a narrative understanding and writing of history (White, 2005).

Although we have seen institutional theory (IT; as renewed by DiMaggio \& Powell, 1983; Meyer \& Rowan, 1977; Scott, 1987) attract increasing interest in OS (Heugens \& Lander, 2009), it has not meant a great boost for an organizational history. It has rather had the effect of pushing back Foucauldian oriented analyses along with its greater concern for history (Kondra \& Hinings, 1998; Philips, Lawrence \& Hardy, 2004). IT, on the backdrop of Weber's theory of rationalization and bureaucratization, nuanced by the bounded rationality concept in the Carnegie school of decision making theory (Cyert and March, 1963), instead gives the environment a greater role. Asking why organizations converge to a similar form, IT scholars question whether Weber's argument - efficiency, predictability, and speed explains it all. DiMaggio and Powell (1983; Powell \& DiMaggio, 1991) suggest that such homogeneity is the result of institutional pressure. Organizations in the same field, part of the same population and sharing the same environmental constraints, will be subject to institutional isomorphism - similarity in structure and approach - for the purpose of obtaining legitimacy or pass as normal. Isomorphism (institutional theory's master concept) would certainly suggest that history is important, but institutional theory locates it beyond the realm of its analytical attention. Isomorphism can be understood as incorporating time whilst simultaneously preventing a historical perspective: it is, if you like, high on the social and allergic to the historical, preventing it also from analysing processes of institutionalization (DiMaggio, 1988; DiMaggio \& Powell, 1991).

Foucauldian approaches and new institutional theory do not exhaust examples of where history comes (or could have come) into OS. However, given the discussion above, it would be safe to say there is a deficit in OS when it comes to historical analyses (Üsdiken \& Kieser, 2004). We believe that a more constructive inter-disciplinary 'conversation' with 
business history could be found (Colli, 2012; O’Sullivan \& Graham, 2010) from which OS scholars could learn more on how to do historically reflexive research (Booth \& Rowlinson, 2006; Popp \& Holt, 2013a; 2013b; Wadhwani \& Bucheli, 2014).

Recently, Rowlinson, Hassard and Decker (2014) have contributed to strengthening and enriching this conversation (cf. Colli, 2012; Keulen \& Kroeze, 2012; O’Sullivan \& Graham, 2010). Rowlinson et al. (2014) have a particular focus on the question of representing the past, which they see as a discussion where we need greater reflexivity in order to understand how history matters for organization theory. However, guided by Ricoeur (2004) and Lorenz (2011), they target the more particular question of the epistemological problem of representing the past, understood as 'the status of narrative, the nature of evidence, and the treatment of time.' (Rowlinson et al., 2014, p. 4). Although this is slightly different from our study of inheritance in FB and the related problematization of the role of history in OS this spurs, where Nietzsche directs us to the question of narrative and the literary/creative in thinking and writing history, it is still highly relevant. Rowlinson et al. (2014) propose three epistemological dualisms (derived from historical theory) as different ways of knowing the past and differentiate historians from organization theorists: explanation, evidence, and temporality. They summarize accordingly (Rowlinson et al., 2014, p. 2):

(1) in the dualism of explanation, historians are preoccupied with narrative construction whereas organization theorists subordinate narrative to analysis; (2) in the dualism of evidence historians use verifiable documentary sources whereas organization theorists prefer constructed data; and (3) in the dualism of temporality, historians construct their own periodization whereas organization theorists treat time as constant for chronology." 
What they do here is to think about the problem of history as an epistemological problem of representation, and to understand 'the status of narrative' in a Ricoeurian fashion by focusing on explanation. Our Nietzschean framing turns us towards other problems - not unrelated but different. With Nietzsche we move away from traditional epistemological concerns with representing and understanding past actions, to instead see inquiring, problematizing and narrating as the processes through which we can increase our capacity to create change, as analysts and writers 'of' this world (past and present) in flux (Deleuze, 2006; Rescher, 1996).

\section{Focus, aim, contribution}

A call for a history-turn in OS, we suggest, can learn from being more attentive to a voice, seldom heard in this conversation: the prevalent form of organization worldwide, the FB. FBs account for around $90 \%$ of all firms worldwide (Aldrich \& Cliff, 2003) and are ubiquitous in advanced and emerging economies alike (Gedajlovic, Carney, Chrisman, \& Kellermanns, 2012). Although many family firms are small (and more than $99.5 \%$ of all firms in the EU are SMEs, Small and Medium Sized Enterprises), many are also medium and large (La Porta, Lopez-de-Silanes, \& Shleifer, 1999). In fact, 44\% of publicly listed firms in Europe are family controlled (Faccio \& Lang, 2002), and 33\% of S\&P 500 firms in the USA are family controlled (Anderson \& Reeb, 2003). We are thus problematizing the role of history in organizations by attending to FBs as its most evident empirical context.

Are there advantages of studying what history does in FBs? We understand FBs as battlegrounds for different and competing narratives of history, different and competing ways of making history narratively present, producing multiple world-views that constitute a source of tension and conflict between generations (Nava, Rania \& Ramona, 2014). The FB typically struggles with succession (Handler, 1994), conflicting value systems (Denison, Lief \& Ward, 2004), and inter-generational tensions (Grote, 2003), all attributing to history some 
form of agency in the present. We address history's agency in the present, and the question of remembering, below. Although powerful in their own ways, neither IT's tendency to focus on environmental pressure resulting in isomorphic production of similarity, nor Foucauldian focus on discourse, power and subjectivity help us to understand the issue of history in FBs. Foucault's concept of effective history, however, reminds us that social theory used in ahistorical analyses will only lead to a highly artificial relationship to the real. In this sense we are indeed guided by Foucault's more genealogical approach, into a narrative-dynamic understanding of history's effectiveness in the present. Effective history '...both refuses to use history to assure us of our own identity and the necessity of the present, and also problematizes the imposition of suprahistorical or global theory' (Dean, 2003, p. 18). An effective history '...deals with events in terms of their most unique characteristics.' (Foucault, 1977, p. 156). Foucault wants to upset the colonization of historical knowledge (via the transcendental and synthetic) to set humans free in their full creative capacity. The inspiration comes from Nietzsche who (in Thus Spoke Zarathustra) condemns our relationship to history as a 'black snake'; history that is root bound, and crawls down our throat to prevent us from speaking.

Given the relatively moderate dialogue between OS and FB research (Popp \& Holt 2013a; Sharma, 2004), our contribution can be understood as intensifying such a dialogue through attention to history, while inviting OS scholars to consider FB as part of their concern. More precisely, our aim is to use effective history (guided by Nietzsche's problematization of history), in order to analyse the issue of FB 'transition' from one generation to the next. Nietzsche invites us to use history to invent life, which makes us writers rather than readers of history. We are placed in a literary relationship to history, with 
agency as authors. We seek to nuance the analysis of the central issue of succession ${ }^{1}$ in FB research (Chua, Chrisman, \& Sharma, 2003; Lee, 2006; Nava et al., 2014; Sharma, Chrisman, \& Chua, 1996), often focused on economic and juridical issues (Gersick, Davis, Hampton, \& Lansberg, 1997), by moving our attention to the problem of history. In our use of the writings of history, a narrative analysis can help us learn how history matters, and articulate and analyse it in a particular FB case: the Berger family of entrepreneurs ${ }^{2}$. The case opens up the issue of history and the power of narrating the past so as to make space for creative movement into the future. Affirming the literary in all history, what it does, the way it is remembered, narrated, and used (Gallagher \& Greenblatt, 2000), we read the case of the Bergers in the historical light of Shakespeare's King Lear - a story of 'family business' transition to the next generation. Literature here helps us focus on what has historical resonance and thus points beyond the particular case. The literary allows us to think history's poetic-narrative multiplicity with Nietzsche (Burke, 1989; O’Connor, 1995) and calls upon us as authors. We thus bite off the black snake's head (in Nietzsche's words), the total-rational singular history, which silences and pacifies us.

This paper seeks to make two contributions. First, we explore how a Nietzschean problematization of history can nuance and reveal new aspects of a key issue in a ubiquitous form of organization - succession in the case of FB. Second, given how history has thus been opened to us, we show how a literary-narrative analysis helps us identify the organizational drama of history-making as a narrative performance.

We will structure the paper in the following way: after a short elaboration of Nietzsche's problematization of history, framing history as present in FBs, we describe our

\footnotetext{
${ }^{1}$ Succession is a crucial stage in the life of a FB (defined as a business governed and/or managed by members of the same family in a manner that is potentially sustainable across generations; Chua, Chrisman, \& Sharma, 1999), involving changes in stakeholders in the family, management, and ownership systems (Brockhaus, 2004).

${ }^{2}$ As illustrated below, the Berger family of entrepreneurs had a family business in Italy, which was transferred from Berger sr. to Berger jr. in the 1990s.
} 
narrative approach and analysis. We then address the issue of succession in $\mathrm{FBs}^{3}$. We analyse these organizations with particular emphasis on how the issue of history is manifest in the stories described by the cases of the Berger family of entrepreneurs and King Lear. We finish by discussing implications and offering concluding remarks for dealing with the problem of history in OS.

\section{Nietzsche's problematization of history}

The context of Nietzsche's problematization of history included a worry, amongst both hermeneuticians and phenomenologists, that history invades thinking and prevents humans from anything but echoing the past. Both Nietzsche (1844-1900) and Heidegger (1889-1976) are strongly influenced by these developments. Heidegger (who appropriates Dilthey's work; Scharff, 1997) radicalized hermeneutics, made it into our being-in-the-world, into ontology, and not simply a methodology for understanding communication or texts. In his search for authentic historical awareness, Heidegger was inspired by Nietzsche's ideas that history has to free the human for the future (Congdon, 1973) and he focused on fate and repetition: fate as an awareness of one's limited possibilities and the significance of choice; and repetition as the handing down of possibilities of existence that makes choosing meaningful.

Nietzsche wanted to free us from an eschatological conception of history; the JudeoChristian (Augustinian) understanding that history moves towards and end or goal. Nietzsche described also Hegel's move - after secularization had destroyed the eschatological - to make history itself into the great judge of all, as dangerous. 'For Hegel, only those actions or events which were "real" (i.e. necessary to the dialectical progress of the World-Spirit) were truly historical. Nietzsche argued that this submission to the "real" tyrannized the human spirit...' (Congdon, 1973, p. 212), subjecting human life to the telos of a metahistorical

\footnotetext{
${ }^{3}$ We know generation (Mannheim, 1952; Pilcher, 1994) is a most complex and disputed concept that is often invoked much too lightly in FB research (e.g. Lee, 2006). In our case of FBs, when the business is to be 'transferred' from one generation to the next, the defining principle is that of kinship descent.
} 
purpose, meaning or end. He was also against the scientific understanding of history that characterized his time, when positivism's empiricism had won ground. For Nietzsche, history is a series of becomings, moving without end (in poetic multiplicity). This is anti-Hegelian. Becomings are achieved by forces (force is what can), but directed by will (to power): 'The will to power must be described as the genealogical element of force and of forces. Thus it is always through the will to power that one force prevails over others and dominates and commands them' (Deleuze, 2006, p. 51).

Nietzsche points us to the child that, 'having as yet nothing of the past to shake off, plays in blissful blindness between the hedges of past and future.' (1997, p.61), and asks how we can create the future by making use of history (Sinclair, 2004). Nietzsche says the child's play must be disturbed, and then 'it will learn to understand the phrase 'it was'...to remind him what his existence fundamentally is - an imperfect tense that can never become a perfect one.' ( Sinclair, 2004) The continuity of history must be questioned so the future opens up. On a grand scale we can imagine the French Revolution as one such opening. On a personal level, the up-coming succession in a FB would represent another case. The rupture or break represents a possibility to act - freed from the burden of history - while requiring an overcoming of one's self as 'delivered' by history (Ankersmit, 2001; Deleuze, 2006) in memory. Whether that moment is affirmed or negated makes all the difference. Nietzsche's problematization of history seeks to help us affirm (power of becoming active) so as to creatively become what we are not yet according to our history (cf. Foucault, 1977, p. 164).

\section{History in the study of family businesses: on memory}

FB succession exemplifies the dilemma of the burden of history and the battle for future: that we can no longer extricate ourselves 'from the delicate net of [our] judiciousness and truth for a simple act of will and desire.' (Nietzsche, 1997, p. 63). The older generation often gets 
to reproduce this delicate net of judiciousness and truth, the burden of history, and the new generation seeks to free their will and make room for their desire to begin their own time, to become vital, so that ' ... anything truly human, can grow.' (Nietzsche, 1997, p. 63). It is of course growth, renewal or innovation in some sense that the new generation of a FB often seeks to achieve. Few want to simply take care of what is transferred to them. The event of succession is discursive in the sense that the single, local event receives its 'eventness' from the historical coding of this as problematic or even traumatic. History invades the individual event and 'scripts' it as a particular drama (Czarniawska-Joerges \& Jacobsson, 1995). This is clearer than ever in the King Lear drama, wherefore it is used in our study. Our point, resonant with Hayden White (1984; 2005; Söder, 2003), is that we need the literary-narrative to get to the real rather than simply the true. The real is always a multiplicity of meanings rather than a specificity of truth. Burke developed a 'dramatistic' method precisely so as to get to the poetic multiplicity of the real history (Burke, 1969; O'Connor, 1995).

\section{Memory - narrating an open past}

Zerubavel (1996) discusses how the agency of history, and its presence in our lives, is very much a question of the social environments, social rules of remembrance, and how we are socialized into mnemonic communities. 'Indeed, being social presupposes the ability to experience events that had happened to groups and communities to which we belong long before we joined them as if they were part of our own past...' (Zerubavel, 1996, p. 290). How 'it objectively was' (Zerubavel, 1996, p. 296) is only of some importance, since we do not remember in the same way, and remembering seems more to be a question of which narratives of the past we tell and how the past gets narrated (Knapp, 1989). Knapp further brings us into a discussion of whether it actually matters - for historical authority - if the past actually happened the way it is told to have happened in historical narratives. For how can we 
know what the meaning of actions or words were at the time they were done/uttered? This takes us to the discussion of narratives and history, and David Carr's and Hayden White's work, where the latter states (already in 1974) that historical narratives are '...verbal fictions, the contents of which are as much invented as found and the forms of which have more in common with their counterparts in literature than they have with those in the sciences' (White, 1974/1978, p. 82, emphasis in original). Massumi (2011, p. 242) further distances us from the idea of the self-grounded subject that registers data with her/his senses by noting that '[a]ll experience becomes personal socially' and that 'all facts are born factoid.' What actually happened is thus never present outside narrations thereof, since what is 'found' in White's description is a factoid, the experience of which becomes personal socially, and what is invented - in social, mnemonic, storytelling communities - is thus what we have come to name 'the fact' (Latour, 1987; Stengers, 2000; White, 1978).

Nietzsche would be the central thinker also in this understanding of history, and indeed of life, as livable, 'tellable,' and possible to make sense of as a literary adventure of overcoming who we are in a continuous creation of our next selves (Shapiro, 1989; White, 2005). History, Nietzsche (1989) said, should serve life. He contrasted history as a lifeopposing science, a will-to-truth with stipulations of an ascetic life, against history in service of life as a creative becoming (Owen, 2007). The child is not only this human that has yet nothing of the past to shake off (an image from the Untimely Meditations), but is also the final stage in the metamorphosis (from Thus Spoke Zarathustra) where Nietzsche continues to contrast the burden of history with the free spirit of the child. The camel (or the ass, which he sometimes used as image instead) is the one burdened by history and historical knowledge and carries all, cannot say no, but only 'ye-a' (like the ass; Deleuze, 2006, p. 178). The first metamorphosis is from Camel/Ass into Lion, which is the critical distancing, the 'holy no' of the one who wants to overcome but who has no 'holy yes' or unhistorical power to become- 
active, to affirm her overcoming, to become a child (Deleuze, 2006, p. 177-178). Here

Nietzsche finds the capacity to begin, to create, which we have commented above is snatched away from the heir in the FB. 'Taking over' the business is rather a becoming-camel than a becoming-child.

\section{A narrative approach and analysis}

\section{A narrative approach}

FBs represent a special empirical context allowing us to affirm the importance of history and to study how it matters in organizational life. Through a narrative approach and analysis, we can include temporality in what we call the empirical, keep life in language, and grasp the 'eventness' of events. We have turned to Nietzsche as a thinker that trusted in the power of the narrative-literary to convey images and generate affect to make our stories more real.

OS has proven to be receptive to social theory, philosophy and literature studies during the last two to three decades. Following the methodological debates in the 1970s and 1980s (spurred not the least by mis/readings of The Frankfurt School; Berger \& Luckmann, 1966; Kuhn, 1962; Winch, 1958), made into paradigmatic differences by Burrell and Morgan (1979), OS seems irreversibly open to such influences. The wave of organizational culture in the 1980s (e.g. Frost, 1985; Smircich, 1983; Smircich \& Morgan, 1982) and its centring on 'meaning' as key to understanding (rather than explaining) organizational everyday life opened OS to the problems of language and language-use (Winch, 1958, had drawn on 'the later' Wittgenstein to problematize language/use in social sciences). Critical frameworks for organizational analysis (Alvesson, 1985; Willmott, 1984), often supported by Foucault's works, added to a certain reflexivity (sometimes only regarding the other) for which the role of not only language but also knowledge and power are understood as genealogically intimate and productive in complex ways. OS's connective capacity (i.e., openness) vis-à-vis social 
sciences and humanities was thereby confirmed in what had become a more heterogeneous discipline in the process (e.g. Clegg, Hardy, Lawrence, \& Nord, 2006).

Narratives, just like successions, are relational rather than individual-subjective realities (Hosking \& Hjorth, 2004). The narrative-literary approach we have prepared above is not reducible to interpretivism as a methodological perspective (Alvesson \& Sköldberg, 2000; Burrell \& Morgan, 1979; Denzin \& Lincoln, 1994; Leitch, Hill, \& Harrison, 2010). Interpretivism focuses on the various forms of contextualized language-use, trying to understand human behaviour and the complex, dynamic and relational quality of social interactions (Cope, 2005; Leitch et al., 2010). We cannot look for the specificity of that which is 'standing under', which would support a truthful explanation. This would be a narrative approach haunted by the scientific love of 'univocity'. Deleuze \& Guattari (1987) called this 'interpretosis', describing how we loose the real by fixating on one-voiced truth. This makes us passive; discover what there is, receive its meaning, depend on institutions that guard this truth/meaning, and this turns us away from creating (concepts). Nietzsche instead directs us to the problem of freedom and creativity and offers a philosophy with the purpose of serving the becoming-active of humans. Nietzsche describes what is also the heir's dilemma in the FB: "'It was": that is the will's gnashing teeth and loneliest sorrow. Powerless with respect to what has been done - it is an angry spectator of all that is past.' (Nietzsche, 2005, p. 158).

A narrative approach is well suited for telling the stories that acknowledge the importance of time without imposing the artifice of (scientific) linearity. For, '[w] hat is found at the historical beginning of things is not the inviolable identity of their origin; it is the dissension of other things. It is disparity.' (Foucault, 1977, p. 142). The issue of succession is related to this history of training the next generation to remember, this cultivation of desire to receive that poses the problem of freedom for the heir. Succession becomes an event of 
reception, a pacifying ceremony, securing continuity while simultaneously preventing the new from surviving under the suffocating univocity of history.

A narrative approach shares the ambition with anthropologists to acquaint oneself with the imaginative universe within which the locals' acts are signs (have specific meaning), as Geertz (1973) once put it. Against the homology of the experts - the generation running the business - stands the paralogy of the heirs (in Lyotardian language, Lyotard, 1984, p. xxv). Against the homogeneity of a consensus regarding how to relate history and future stands the heterogeneity of multiple language games, petits réceits, welcoming poetic multiplicity (de Certeau, 1997; White, 2005). We find both our cases, the Bergers' FB as well as Shakespeare's 'FB', to inform our analysis of the problem of history in organizations. There are possibilities to generalize this problematic: talk about path-dependence (Editors, 2010; Schreyögg and Sydow, 2011), the paradox of learning (e.g. Paavola \& Hakkarainen, 2005), or how institutions contextualize creativity (Hargadon \& Douglas, 2001). Our aim, however, is to conduct a more nuanced problematization of history in the case of FB succession. Juxtaposing two literary-narrative texts, Bergers' auto/biographical and Shakespeare's theatre, we get closer to the real problem: the openness of history offers heirs a potential freedom that the imposed univocity of their parents' historiography threatens to deny.

'Practice is a set of relays from one theoretical point to another, and theory is a relay from one practice to another.' (Foucault \& Deleuze, 1972/1977, p. 206). Thus, narratives can contribute to theory development through the richness of their contextualized accounts and the level of precision in their descriptions (Colquitt \& Zapata-Phelan, 2007). Theory is this way built/developed not by absolute generalization (axioms, laws), nor by statistical generalization (sample to population), but through patterns of meanings and conceptual bridges (resonance in life worlds; Greenblatt, 1990; Schutz, 1964) following an analytical 
induction (Williams, 2000). History, thought with Nietzsche and de Certeau, locates our analysis to "...the juncture of scientific discourse and ordinary language, in the same place where the past is conjugated in the present, and where questions that are not amenable to a technical approach reappear in the form of narrative metaphors.” (de Certeau, 1997: 215). To us, succession in the FB is one such question.

The narrative approach is well developed in sociology (e.g., Abell, 1987; 2004; Franzosi, 1998; Polkinghorne, 1988), OS (Czarniawska, 1997; 1998), and entrepreneurship/FB research (e.g., Dawson \& Hjorth, 2012; Gartner, 2007; Hjorth \& Steyaert, 2004; Jennings, Perren, \& Carter, 2005). This approach can help address FB problems in a way that goes beyond calculation and strategic decision making, by encompassing the lively, moving, creative, and dramatic characteristics of family relationships (Hjorth, 2007).

Paralleling the case of the Berger family with that of Shakespeare's King Lear is a way to guide our analysis by having the resonance between the cases highlight what is central to us: the issue of history in the FB is more accurately available to us in the literary-narrative language. The use of parallel autobiographical and literary stories on this topic highlights the dynamic relationship between 'life and literature'. This is a Harold Bloom (1998) thesis wherein he suggests that Shakespeare invented the human: life and literature form a continuous (edifying) companionship. Shakespeare, as a dramatist, intensifies the unstable boundary between the literary and the non-literary, which constantly informs human imagination (Greenblatt, 1984) and discloses history’s openness to potential life.

\section{Narrative analysis}

Narrative analysis can be approached in several different ways, but they obviously all focus on narrative forms of knowledge: this is how people become knowledgeable, show that they 
know, and transfer knowledge, by narrating (Lyotard, 1984). In this paper, we draw primarily on the work of Barbara Czarniawska's (e.g. 1999; 2010) and argue for applying Burke's (1968) pentad as a structural framework to analyse the socially constructive dynamics of narratives (Czarniawska-Joerges \& Jacobsson, 1995; O’Connor, 1995; 2004).

Narratives keep life in language, and are defined as the result of a structuring process of making a 'story' or 'tale' by means of chronology and plot (Czarniawska, 2004). The plot explains how we go from one state to another. Through a narrative approach, we can analyse an individual's personal or autobiographical story and investigate how such a story occurs in relation to other stories (Fletcher, 2007; Hosking \& Hjorth, 2004). In a genealogical-narrative approach (Hjorth, 2004), in addition, we attend in particular to the dynamics of stories' becomings, how facts are born factoid, and the tension between stories as performative acts and their relationship to a history that seeks to totalize and homogenize.

Analysing a story requires contextualization, a sense of the time of the plot, and identification of rhetorical devices used by the narrator in crafting the story. Thus events, which are arranged in a chronological but also logical sequence, form the basic building blocks of a narrative. By describing a journey from one situation to another, caused by some event in a story that disrupts an initial state of order and sets in motion a reversal of fortunes, we provide a plot (Franzosi, 1998). When drama, affect and the multiplicity of language are important to our analysis, Burke's (1968) pentad provides a structural framework to analyse the socially dynamic force of narratives (Feldman, Sköldberg, Brown, \& Horner, 2004; O’Connor, 1995). Burke places emphasis on poetic rather than semantic meaning, stressing that the '...poetic plays with multiplicity, not specificity.' (O'Connor, 1996, 788).

For this, phenomenology is too concerned with the structure of consciousness and still too centred on the subject; discourse analysis may lure you into a too close reading of the written texts only; and hermeneutic depth-understanding, as pointed out above, is drawn 
towards a foundation; Garfinkel's and Goffman's ethnomethodological interpretivism better fits ethnographic material from live observation, but also shares the problem of interpretosis. Instead, Burke's pentad, helping us reveal the drama of stories, is more apt for narrativeliterary analyses (O'Connor, 2004). The pentad holds together the following five elements: act (What takes place? What is done?); agent (Who acts?); agency (How is the act carried out? What means are used?); scene (Where does the act take place? What is the background/context?); and purpose (Why does the agent act?). This 'dramatistic' method of inquiry (O'Connor, 1996) helps us reveal what what people say does, and how history gets in their ways by offering itself as a gift.

\section{Presentation and analysis of cases of FB succession}

The presence of history in the FB can be seen in some of the crucial topics that are often studied in FB research, such as leadership succession, knowledge transmission, and corporate culture (Lee, 2006; Litz, Pearson, \& Litchfield, 2012), all of which are, by their nature, about the 'long run' (Colli, 2012). Families share history and accumulate experiences, which are subject to different interpretations by different family members, and FBs can gain great strength from their shared history, identity and language (Gersick et al., 1997). At the same time, families have personal stakes that are deeply rooted in generations of family and business history (Carlock \& Ward, 2001) and conflict among family members can endanger this. Often FBs have a hard time mapping and creating their future because they overlook their history and take it for granted (Hubler, 1999).

A ‘lifelong common history’ can have advantages and disadvantages (Tagiuri \& Davis, 1996). Members of the same family have shared experiences and probably different narrative recollections of those. Family history is impossible to separate from the FB history, and Tagiuri and Davis (1996) also noted that early disappointments can have negative effects 
on trust and may lead individuals to avoid work situations with other family members for fear of being disappointed again. Disappointment, living up to expectations, handle trust: everyday FB life.

Generational succession is a constant theme in FB research. De Massis, Chua, \& Chrisman (2008) provide an overview of the problems involved as they construct a model of what prevents intra-family succession (cf. Nava et al., 2014). Cadieux (2007) provides a typology of roles predecessors take during and after instatement of successor. This is when the 'hawk-syndrome' typically needs to be avoided (predecessor hovering above the successor). Research further shows that it is often the predecessor that initiates the process and suggests to the successor-candidate that s/he indeed should become one. Predecessors take on two types of roles in the withdrawal phase: roles related to the organization and roles related to the successor (cf. Lam, 2011). The key is that predecessors step back from governance of the firm. However, they may remain involved in other forms such as mentoring (Lam, 2011). Tatoglu, Kula, \& Glaister (2008) have shown that the complexity of FB succession process is not the least referable to the fact that only around $40 \%$ of predecessors select successors. That succession is difficult is probably also reflected in the statistics of firm-survival. Only $30 \%$ make it to the second generation, and only $12 \%$ persist to the third (Family Firm Institute, 2013). Several other factors obviously play a role in this, but succession difficulties are surely amongst them. Fox, Nilakant, and Hamilton (1996) suggest that the succession process should be managed or facilitated by a third party, to professionalize the process and subject it to managerial expertise.

Our empirical analysis focuses on paralleling the autobiography of an entrepreneur, Tommy Berger (Berger, 2007) and re-storying of the history by his son, Roberto Berger 
(Astone, 2009), with Shakespeare's tragedy of King Lear. In the drama ${ }^{4}$ of Tommaso (Berger sr.) and Roberto (Berger jr.), Berger sr. seeks to control the future by interrupting history, sidestepping his son as heir of the 'empire'. Lear seeks to secure the most efficient pension for himself by singling out the one, amongst his children, that loves him the most. Why autobiography in the case of the Bergers and not interviews? Autobiographic material provides access to narration that expresses results of reflection. This is important in cases of succession, when history is what you need to deal with, since the parties' intentions are crucial for understanding what they believe they are doing/saying. A fiction, such as Shakespeare's King Lear, has the advantage of being able to read the minds of several people and shift between perspectives in ways that ethnography seldom has the chance to do.

\section{The story of the Berger family}

Berger sr., born in 1929 in Austria, built on his grandfather and father's business to create a food empire in Italy, which included Hag decaffeinated coffee and several bottled mineral waters (e.g., Fiuggi, Sangemini, and Levissima). Berger sr.'s autobiography is in itself an emphasis of the importance of history.

This book is dedicated to my grandchildren ... whom I practically don't know, so that they can learn about the story of their family and so that in their life they may always be honest, loyal and truthful, therefore be 'just,' and may always hold their heads high. (Berger, 2007)

It is divided into three parts and the first one is entirely dedicated to the history of his family, from when his grandfather founded the Berger factory in Vienna in 1890, to his grandfather's success, to the killing of his grandfather by the Nazis in 1938, the persecution of his (Jewish)

\footnotetext{
${ }^{4}$ We have analysed this case in a previous study (Dawson \& Hjorth, 2012), with a different purpose, and will to some extent draw on descriptive presentations.
} 
family, the escape to Italy, and the recreation of the business by the father through the purchase of various businesses in Switzerland and Italy. In his autobiography, Berger sr. writes about his son's privileged upbringing and, once he joined the FB, subsequent bad decisions about risky investments in new economy firms (Berger, 2007). Because Berger sr.'s lack of confidence in his son, when he started thinking about retirement, he decided not to transfer the family empire to his son but to sell it. In 1992, Berger senior put his wealth in a trust fund ${ }^{5}$. He describes how the rules regulating the trust were changed over time and how, ultimately, he was excluded from the trust. In 2004, Berger sr. sued his son Roberto and advisers for fraud. They reached a settlement in 2006. Berger sr. died at the age of 80 years, in 2009, and all the major Italian newspapers reported his death alongside his (version of the) story (e.g., Corriere della Sera, 2009). The same history, told by the son Roberto, appears quite different. This is reported in a chapter of a book written by a journalist (Astone, 2009) on Italy's latest generation of FB owners and managers.

\section{The tragedy of King Lear}

In order to go beyond a rational decision making approach to succession and focus on its dramatic-relational process, we consider Shakespeare's King Lear as a generic example. Both men, Lear and Berger sr., experienced a similar problem, namely that of arranging for succession and thereby transferring family wealth to next the generation.

Shakespeare sets the scene by relating the tale of the fictional King of England, Lear, who gathers his three daughters and his courtiers, and announces he wants to give up his crown by dividing his kingdom: 'Know that we have divided / In three our kingdom: and 'tis our fast intent / To shake all cares and business from our age' (Shakespeare, 1968, p. i.i.36). However, he declares that his final decision regarding the division of the kingdom will be

\footnotetext{
${ }^{5}$ A trust fund is a legal arrangement governing intra-family wealth transfers, whereby property is managed by a trustee (or trustees) for the benefit of other individuals, in this case himself and his children.
} 
based on how much his daughters love him: 'Tell me, my daughters, / (Since now we will divest us both of rule, / Interest of territory, cares of state), / Which of you shall we say doth love us most, / That we our largest bounty may extend / Where nature doth with merit challenge' (p. i.i.47). The first two daughters proclaim their love in no uncertain terms. Goneril, the eldest, says: 'Sir, I love you more than words can wield the matter; / Dearer than eyesight, space and liberty; Beyond what can be valued rich or rare; / No less than life, with grace, health, beauty, honour’ (p. i.i.54). And Regan announces: ‘... I profess / Myself an enemy to all other joys / Which the most precious spirit of sense possesses, / And find I am alone felicitate / In your dear Highness' love' (p. i.i.71). King Lear then turns to his youngest daughter, Cordelia, who says: ‘... I love your Majesty / According to my bond; no more nor less' (p. i.i.91). It is of course significant that Shakespeare makes her use 'bond' to describe her relationship, described as what binds or ties something together (www.oxforddictionaries.com). Is that bond her being the 'next generation?'

Lear hands over his kingdom to daughters Regan and Goneril, who he believes truly love him, and announces that he intends to stay with each daughter in turn, accompanied by one hundred loyal knights. In doing so, Lear starts his own tragedy by a foolish misjudgement: he 'resigns his sceptre to a chorus of acclamations... The incident is profoundly comic and profoundly pathetic... It is childish, foolish - but very human. So, too, is the result... It is, indeed, curious that so storm-furious a play as King Lear should have so trivial a domestic basis' (Knight, 2001, p. 182). Lear's own reflection on this is telling the Earl of Gloucester: 'When we are born, we cry that we are come to this great stage of fools.' What happens next is a sequence of situations and actions, as well as parallel subplots, starting with Lear's daughters Goneril and Regan undermining his authority and ordering him to reduce his entourage and eventually leading to King Lear's madness and the death of all the main characters. 


\section{Analysis of the two cases}

In his autobiography (Berger, 2007), Berger sr. tells his (version of the) story of how he was slowly excluded from the legal trust, and his children went from being its beneficiaries to controlling it. Berger jr. is not ready to accept the inevitable continuity of history. He seems not to perform according to his father's expectations. More importantly, he refuses to accept the patriarch's authority over him and the business, and acts his reaction to Berger sr.'s attempt to maintain control over the business. Berger sr. has a strong sense of allegiance within the family and expects it from his children. He writes: 'From [my children] I expect to receive ... obedience' (Berger, 2007). Berger sr.'s negativity, will to nothingness, is battled by Berger jr. He is reacting against a vision in which 'children are suitable for succeeding to their fathers only if they are mere executors of their will, if they manage to shed their soul and personality and play the part of the ghost of their parent.' (Astone, 2009). Berger jr. affirms his history as FB owner, but only by creating his own start. A start that is built on a break that in itself affirms the openness of the future - a release from the teleology of history's end or meaning. Following the publication of the autobiography, Berger jr. started legal action for defamation against his father and the publisher of the book. He also wrote a memorial in which he explained that conflict between generations was caused by deep differences on how to manage the family wealth and by the father's confusion between personal and business wealth (Astone, 2009).

What are the implications of the Lear-story from the perspective of our research interest in the relationship between the issue of history and succession in FBs? Although we present a very limited and compressed version of the drama, we suggest we read Lear as a 'high man' in Nietzsche's terminology; one that placed considerable constraints on his daughters, by embedding the succession in a strange calculation of love. The two elder 
daughters take part in this game by reacting to it according to the implied rules: the one that loves the most gets most. 'King Lear is a tragic vision of humanity, in its complexity, its interplay of purpose, its travailing evolution. The play is a microcosm of the human race' (Knight, 2001, p. 202). Shakespeare is in this play almost as sceptical regarding human's possibilities to free themselves from the burden of history as was Nietzsche. According to Harold Bloom (Bloom, 1998) we would say Shakespeare's story teaches us to respect the impossible: there often is no happy mix of family and business as the business side makes attempted acts of love inevitably pass as investment, emphasizing family as an economy ${ }^{6}$ (Nava et al., 2014). FB histories often have a king, a fixation on a founder or a previous incumbent. Such individualization of the business inevitably makes succession, as in Lear's case, into an assessment of the person. Shakespeare simply intensifies this by boiling it down to the central question: do you love me enough to receive my precious gift? This invites the reactive response, the confirmation of the 'it was' (Nietzsche's imperfect tense) and a reinstalment of being, handed down from history: will I be continued in you?

Through Burke's (1968) pentad, we can see that the requirement of succession in the $\mathrm{FB}$ - that both parties (both actors, active as one giver and one receiver) in the relation constituting the scene for the succession act, affirm the act as taking place due to love (agency) and for (the purpose of) securing the coming generation's welfare (including happiness and health and not simply fortune) - is perhaps unattainable. In this sense it mirrors Derrida's (1992) analysis of the gift as being only possible as an unanticipated, unexpected, unconditioned, unforeseen, and irruptive event. Derrida (1992, p. 12) notes: 'For there to be a gift, there must be no reciprocity, return, exchange, counter-gift, or debt. If the other gives me back or owes me or has to give me back what I give him or her, there will not have been a gift, whether this restitution is immediate or whether it is programmed by a complex

\footnotetext{
${ }^{6}$ And the Greek oikonomia is indeed describing 'household management.'
} 
calculation of a long-term deferral or difference.'. You cannot expect a gift, for you would annul it. And, the other way around - you cannot give, expecting the receiver to react as someone who has been waiting for this gift. Then again, the gift is reduced to investment, to transaction, to exchange.

--- Insert Table I about here ---

Burke's pentad invites to analyse more in depth the tensions between the roles and the personalities as played out in organizational settings. FBs are distinctly characterized by intensifying the tension between the public/official role as manager or owner and the personal identity as mother, father, or heir. This tension unites our two empirical cases and is the basis for King Lear's deep tragedy. MacIntyre's (2007) conceptualization of 'character' provides the link between public and private (different scenes; Czarniawska-Joerges \& Jacobsson, 1995): ‘...the requirements of a character are imposed from the outside, from the way in which others regard and use characters to understand and to evaluate themselves.' (MacIntyre, 2007, p. 29, emphasis in original).

It is the demand that the role and personality should fuse, and be reproduced and maintained by members of socio-cultural settings such as FBs, which is specific to a character such as owner-manager. 'The character', MacIntyre (2007, p. 29) writes, 'morally legitimates a mode of social existence', which further provides a certain social script for relating to this character. Father and owner (or father and king), two different agents and agencies in Burke's dramatism, are expected to fuse in one character. The character of patriarch (defined by Oxford Dictionaries as 'an older man who is powerful within an organization') is so dominant in the organizational contexts of FBs and kingdoms that it prevents the personal father from taking part in social life. We could thus analyse the narratives as exemplifying acts (succession) by agents (king, owner) in which the purpose (love or securing wealth, legacy, continuity) is interpreted according to the scene (except by 
Cordelia who sees through the official script and focuses on the father), resulting in disillusioned givers whose agency - in both our cases - should have been love (in the case of a father) but is performed as calculated strategy (by an owner).

In a situation where Lear poses as altruist, we can identify the double failure of his act: 1) he is indeed injecting his act with expected reciprocity and, by doing so, fails to see that the daughters who fear (agency) him actually play their parts perfectly by reciprocally answering Lear's act with what it demands: lip service love (purpose); 2) giving is indeed not possible in the context of families transferring wealth, and even less so in contexts of FB transferring family wealth; for it cannot fail to be expected. This brings us to the entrepreneur Berger sr., who, in line with Hirshleifer's (1977) recommendations, sets up a legal trust (new scene) as an 'instrument of parental control' (agency) in order to retain the last word (purpose).

In his autobiography, Berger sr. is the natural main actor, but there are several others including his children and advisers. The act proceeds through 45 years of Berger sr.'s life, in which he escapes poverty to create a business empire and, later, decides to leave his businesses to a legal trust. The agency consists, on the one hand, of Berger sr.'s entrepreneurial skills and, on the other, of his account of his children's 'conspiracy' to exclude him from the trust. The purpose is the moral of Berger sr.'s story. His autobiography contains two moral themes that are typical of tales of entrepreneurship (Smith \& Anderson, 2004). The first idea is the social promotion of entrepreneurship, through an emphasis on independence, perseverance, and the importance of success. The second theme is the promotion of particular values for entrepreneurship, through an emphasis on how it should be ethical (Ahl, 2007). This is communicated in Berger sr.'s autobiography by the 'falling from grace' of those who do not adopt entrepreneurial principles of hard work, independence, prudence, honesty, and decency (Smith \& Anderson, 2004). Berger sr. portrays his son as 
having delusions of grandeur, wasting money, and being self-centred, unable to make tough decisions, and easily influenced by other people: ‘...in Boston, he went to university and graduated in Business Economy. But Roberto had not really matured. What had grown were especially his delusions of grandeur. . . In 1982, when he graduated, I went to Boston for the ceremony ... Four days later . . . the hotel presented me with a two thousand dollar bill [because Roberto had gone golfing], plus another two thousand for telephone calls to Italy.' (Berger, 2007). Astone (2009, who wrote junior's version) notes, himself in a high-pitched tone, that ' $[\mathrm{N}]$ ever in history has a father resorted in such a strong manner to shame his son.' (Astone, 2009, p. 126).

\section{Discussion}

There are some striking parallels between Lear's and the Berger story. This is because all their acts are made, composed, fashioned - by Shakespeare, journalist interviewing and writing for Berger jr., Berger sr. autobiography, and us (Geertz, 1973; Greenblatt, 1997). Also the Bergers' acts are made, composed, fashioned when they first took place, and are as such already signs in a culture and history. The story of Lear is literature, while that of the Bergers is biography, but we see both emerging in different techniques for recording and narrating experience, and our analysis wants to affirm Greenblatt's point that the literary and nonliterary are each other's thick descriptions (Greenblatt, 1997, p. 22).

In our stories, following a turning point, the main actors no longer seem to have control over subsequent situations and actions. The succession they had planned as an event of reception on the part of the children, in order to secure continuity, goes through great intensity and 'feverish agitation' and sees the receivers (the successors) freeing themselves from the burden of history by imposing their own paralogical petit récit, taken as 'blissful blindness' of an unhistorical life 'between the hedges of past and future' (Nietzsche, 1997). 
Narrative momentum (life in language) in itself seems to be a great force which requires 'will to power' to be altered. Berger sr. interrupts the building of an empire, sells off and creates a trust to manage the money. He denies his son 'co-authorship' in the FB-story. Berger jr. forces a new chapter into the story by bending the dot into a comma in court, wrestling authorship from his father and taking command of the pen. However, there are also some notable differences. Whereas King Lear undergoes mental conflict, agony and, ultimately, explosive madness, Berger sr. later comes to realize that he is being pushed out of the family trust and portrays himself as a 'victim' of other agents' purpose. This becomes his plot. It raises several questions over why the process that has been set in motion (i.e., the father being pushed out of the trust) does not change trajectory at any point in the story. It would seem that Berger sr. realizes what is happening. In the autobiography, he writes: 'Why do I endure this situation? For love of a quiet life. And because I would have never, I repeat never, believe that they were tricking me. Could I imagine that my son was tending a trap?' History's authority is what makes Berger sr. blind to the trap. Berger sr. imposes his story on jr. by trying to end it all rather than just 'his chapter.' Berger jr. interrupts this becomingreactive. When active forces are separated from what they can do, our capacity diminishes (what Spinoza called 'sadness'; Deleuze, 1988). The prize is the full break with his father. The family and business metanarratives are necessarily intertwined in FBs (Nava et al., 2014).

Another key difference between the two stories lies in the trigger for the chain of events: in King Lear's case, it is his childish and foolish decision to base the succession plan on a declaration of love, whereas in Berger sr.'s case it is a more formalized and (seemingly) better plan of creating a legal trust. Despite the latter being managed as a planned process, as is advocated in the literature (Le Breton-Miller, Miller, \& Steier, 2004), something goes wrong. Succession highlights the complexity of the relational dynamics between generations 
(Lee, 2006). It also surfaces the problematic questions of the private and public, of family and business, and of history and freedom. Problems arise perhaps because of the creation of a legal trust, which is Berger sr.'s attempt to invest in internal control mechanisms (Schulze, Lubatkin, \& Dino, 2001), meaning he is individualizing the decision, prioritizing his history, and claiming sole authorship to the FB narrative.

Let us move on to explore the implications of having opened up succession to something beyond economy. This invites the drama of the FB relationship and Burke's pentad helps us analyse this too (see Table I). First, we can investigate how entrepreneurs and other actors interpret and enact succession by analysing the agency (Berglund, 2007; Burke, 1968). In Berger sr.'s case, he carries out succession by creating a legal trust. However, different actors may have different perceptions of the act: whilst the father may have created a legal trust because he has his children's future wealth in mind, the latter may perceive it as an indication that the he wants to manage these resources rather than simply transfer ownership of the FB. We can also focus on the actors' purpose. In the autobiography, Berger sr. says 'My philosophy is straightforward: as a father, I believe I must provide for my children and their offspring, and from them in return I expect to receive what is right i.e., honesty, sincerity, and obedience.' This raises questions such as: whose welfare is Berger sr. really looking after? Also, how does this reciprocity work: does he want obedience for money? There seems to be a clear expectation in both stories: Berger sr. expects obedience, whilst Lear expects to be hosted by his daughters.

Second, FBs are an obvious case for genealogic inquiries due to the constant presence of history in such organizations. Attention to the genealogical and contextual nature of phenomena means we actively include the historical, social and cultural context - the scene, to use Burke's (1968) terminology. This helps us understand the individual as relationally constituted by layers of history and significant others. The importance of history is well 
illustrated in the Berger sr. case. He writes 'I was a Jewish adolescent who had run away from Italy... I wasn't even 14 years old, and there I was alone... with two rolls of gold coins and the aim of escaping from the Nazis... My children grew up as privileged individuals. I thought 'I want them to have the childhood and youth that were taken away from me'. Therefore I avoided upsetting them and never told them about my past.' He also writes 'In 1999, my American accountant had tried to warn me, but his suspicion over [my son] and the others... were inexplicable. What did [the American accountant] know about the values on which, in our country, a family is based?' A genealogic inquiry locates 'family' in two different times/places and study how its meaning radically differs between generations, which in turn can help us understand how an act can pass as altruism for one actor whereas for the other is does not (Kertzer, 1983).

Third, by opening to the complex nature of FB succession the multiplicity of history becomes evident. In Berger sr.'s case, his understanding is strongly influenced by the tragic story of his family as well as the story about business values inherited from his father (family and historical context). Berger sr.'s decisions and actions, based on this understanding of his role and of trust, assume that his children share this perception, which evidently is not the case. Berger sr. cannot comprehend the result, but tries to explain it by suggesting they 'have forgotten what love and gratitude are' (Berger, 2007, p. 10). A narrative approach allows us to embrace this multiplicity of narrative histories in FBs.

Fourth, King Lear and Berger sr. clearly belong to different historical periods, and still the event that unites them, the transfer of 'the business' from one generation to the next, suffers from the re-productive capacity of a 'imperfect tense' and a historical character: expectation to apply a skeptical attitude towards the younger generation's worthiness and capability to take on the mantle of leader. The younger generation in turn seeks to shrug off this continuity by accomplishing a new start (as in the Bergers' case) or by focusing on the 
personal relationship rather than a historically scripted agent/scene, in which they are expected to perform (as in the case of Cordelia). Both ways exemplify an urge to create space for will and desire, to start anew: to make the older generation's act into perfect tense (finished past) and thereby release that freedom to act that belongs to the Nietzschean unhistorical, which cannot be imposed on you (as in Berger sr.'s attempt), but has to be achieved by the younger generation.

\section{Concluding remarks}

Through a narrative approach we have attempted to answer calls for greater historical attention in OS, by focusing on a pervasive form of organization - the FB. Aiming to problematize history, we invited Nietzsche to guide us and hope to have shown how OS could benefit from attention to history, and how FB studies can be part of OS. FBs are organizations saturated with a heritage that is somehow meant to be passed on and, therefore, meant to be carried on. In this sense, the story of the FB is a natural empirical ground for inquiring the role of history in OS. This should indeed be written in a passive voice since a passive voice is part of the problem of history. Nietzsche is the one that most forcefully, precisely and elegantly articulated this diagnosis in his Untimely Meditations and Thus Spoke Zarathustra. Also here there is a 'performative' element in using Nietzsche as our support, for his style (Danto, 1991) as such (narrative, aphoristic, literary; cf. Rhodes, 2009) puts into question how the past is told and what this means in terms of knowledge (Carr, 2007; 2008; White, 1984). Our choice to learn from Nietzsche means we are inviting the view that history is narrated, open and multiple (White, 1984); pressing 'it was' upon us, writing us (Foucault, 1977); disturbing but also powering up our playful access to write history, which to some reflects a philosophy that paved the way for a relational ethics of a vitalist, life-affirming kind, including feminism (Butler, 1990; Gatens, 1996; Grosz, 1994; Stone, 2005), while to 
others it represents a marginalization of a 'herstory" ${ }^{7}$ (Stone, 2005).

Nietzsche's point with describing human existence as imperfect is that history is both a burden and a gift - for the heir of a FB as well as for the writer attentive to history in OS. History is simultaneously what prevents the human from exercising will and to affirmatively act, and what later on (in Thus Spoke Zarathustra) will provide the blessing or overcoming of this crippled status in the embracing of the eternal return. It is significant that Nietzsche uses the expression of imperfect, the unfinished past act, whereas perfect refers to a finished past act. This is highly resonant with our problematization of history in the case of FB succession. The burden of history then is also this expectation of acceptance, by the receiving part of the family to go under the yoke of an unfinished act that is not supposed to be finished under their generation either - they are, in effect, doomed by historical necessity to become caretakers, trustees. Thus, there is no beginning available, especially not if an end is forced upon you as in the Berger story. The Nietzschean 'it was' is handed over to you. Finishing it cannot be the older generation's task - as in the Berger sr. example - but the younger generation's decision. The heir has to overcome her/his history, start a new chapter. This cannot be done for you. The imaginative opening towards what we can become (cf. Parker, 2011; Rhodes, 2009; Winnicott, 1971), again central to Nietzschean problematization of history, would otherwise be closed to the heir as they are assumed to step into the prescripted character/story.

Nietzsche's problematization of history shows how FB organizations link history to OS, serving as a rich example of how the past and future are constantly negotiated in the present. Instead of letting history 'invade' their thinking in an eschatological way, individuals - as seen with the successors in both our cases - often want to make use of rather than be used by the past. Rather than receiving the past as a way of securing continuity, successors

\footnotetext{
${ }^{7}$ Herstory of course builds on a partly correct etymology of history, which directly has little to do with the pronoun 'his,' but with Latin and Greek historia meaning narrative inquiry. However, a histõr was also a 'wise man, judge' the etymological dictionaries tell us (e.g., www.oxforddictionaries.com).
} 
want to un-burden themselves, escape Nietzsche's camel, via the roaring 'no' of the lion, so as to make room for the will and play of the child. This may help explain the low survival rates of FBs going from first to second and, especially, from second to third generation. By bringing FB into OS, history is centred. Regardless of what triggers the chain of events or actors' reactions (e.g., Lear's agony or Berger sr.'s acceptance), problematizing history in succession highlights the complexity and intricacies involved in being an actor, fusing one's role (as father and business owner/king) and one's personality (MacIntyre, 2007).

Accepting Nietzsche's gift - a certain problematization of history - not only means we can highlight novel aspects of the study of FB organizations. It has also meant a burden for our analysis and a challenge for OS more broadly since we seldom attend to will and force the 'naked' way Nietzsche invites us to. In effect, 'thinking history' with Nietzsche demands from us to overcome who we are in our own comfort as analysts. Our study highlights how the tendency in entrepreneurship and FB research to focus on the individual entrepreneur and his/her psychological or cognitive capacities is a clear reduction/limitation. Historical-narrative analysis instead carries the relational, dramatic nature of social realities to the fore (Fletcher, 2007; Franzosi, 1998). History's presence in FB organizations becomes more apparent, preventing us from seeing the past as 'merely a repository of ready-made data' (Rowlinson et al, 2014). A narrative approach has the capacity to bring into higher resolution the memories/stories/archives we study to learn how history is narrated, and how history matters for world- as well as sense-making in the present. It holds this capacity not the least by being attentive to how language is used in real time, and by focusing on the role of time and timing for the construction of chronology, causality, and the rhythmic basis for convincing story-making (Georgakopoulou, 2003).

FB practitioners, owners of privately held firms and their advisers, should focus on evaluating and engaging in issues of succession and value transfer between generations from 
a historical perspective. Thus, practitioners need to identify the most influential stakeholders and contextualize their perceptions of their own and others' actions within the historical, social, and economic background, in order to understand the processes and mechanisms that are associated with value transfer between generations. Finally, working with a form of knowledge that is practised in the field, researchers using narrative approaches can find themselves in a position to converse with practitioners without heavy-handed translation of research results (Fletcher, 2007; Gartner, 2007). FB founders and heirs, as well as those involved in transferring wealth, can also learn from the insight that succession cannot be reduced to an economic act, for as such it becomes a ruin (as our cases have shown). Also, in order to meaningfully distinguish succession from investment, a social, historical, and cultural contextualization seems crucial in any attempt aimed at understanding how (agency) and why (purpose) this act, in this particular scene (FBs), was undertaken by the agent(s) in the first place. 


\section{References}

Abell, P. (1987). The syntax of social life: The theory and method of comparative narratives. Oxford: Oxford University Press.

Abell, P. (2004). Narrative explanation: An alternative to variable-centered explanation? Annual Review of Sociology, 30, 287-310.

Ahl, H., (2007). Sex business in the toy store: A narrative analysis of a teaching case. Journal of Business Venturing, 22(5), 673-693.

Aldrich, H. E., \& Cliff, J. E. (2003). The pervasive effects of family on entrepreneurship: Toward a family embeddedness perspective. Journal of Business Venturing, 18(5), 573596.

Alvesson, M. (1985). A critical framework for organizational analysis. Organization Studies, $6(2), 117-138$.

Alvesson, M., \& Sköldberg, K. (2000). Reflexive methodology - New vistas for qualitative research. London: SAGE.

Anderson, R. C., \& Reeb, D. M. (2003). Founding-family ownership and firm performance: Evidence from the S\&P 500. Journal of Finance, 58(3), 1301-1328.

Ankersmit, F. R. (2001). The sublime dissociation of the past: Or how to be(come) what one is no longer. History and Theory, 40(3), 295-323.

Astone, F. (2009). Gli affari di famiglia. Fatti e misfatti della nuova generazione di padroni [Family affairs: Deeds and misdeeds of the new generation of masters]. Milan, Italy: Longanesi.

Berger, T. (2007). Onora il padre: Autobiografia di un imprenditore [Honor the father: Autobiography of an entrepreneur]. Venice, Italy: Marsilio.

Berger, P., \& Luckmann, T. (1966). The social construction of reality - Sociology of knowledge. New York: Penguin Books.

Berglund, H. (2007). Researching entrepreneurship as lived experience. In H. Neergaard \& J. P. Ulhøi (Eds.), Handbook of qualitative research methods in entrepreneurship (pp. 7593). Cheltenham: Edward Elgar.

Bloom, H. (1998). Shakespeare: The invention of the human. New York: The Berkley Publishing Group.

Booth, C., \& Rowlinson, M. (2006). Management and organizational history: Prospects. Management and Organizational History, 1(1), 5-30. 
Brockhaus, R. H. (2004). Family business succession: suggestions for future research. Family Business Review, 17(2), 165-177.

Burke, K. (1968). Dramatism. In D. L. Sills (Ed.) International encyclopedia of the social sciences (pp. 445-452). New York: Macmillan and Free Press.

Burke, K. (1969). A grammar of motives. Berkeley: University of California Press.

Burke, K. (1989). On symbols and society. J. Gusfield (ed.). Chicago: University of Chicago Press.

Burrell, G., \& Morgan, G. (1979). Sociological paradigms and organizational analysis. London: Heineman.

Butler, J. (1988). Performative acts and gender constitution: An essay in phenomenology and feminist theory. Theatre Journal, 40(4), 519-531.

Butler, J. (1990). Gender trouble: Feminism and the subversion of identity. London: Routledge.

Cadieux, L. (2007). Succession in small and medium-sized family businesses: Toward a typology of predecessor roles during and after instatement of the successor. Family Business Review, 20(2), 95-109.

Carlock, R. S., \& Ward, J. S. (2001). Strategic planning for the family business: Parallel planning to unify the family and business. New York: Palgrave.

Carr, D. (2007). Commentary on 'Placing the past: "Groundwork" for a spatial theory of history'. Rethinking History, 11(4), 501-505.

Carr, D. (2008). Narrative Explanation and its Malcontents. History and Theory, 47(1), 1930.

Chua, J. H., Chrisman, J. J., \& Sharma, P. (1999). Defining the family business by behavior. Entrepreneurship Theory and Practice, 23(4), 19-40.

Chua, J. H., Chrisman, J. J., \& Sharma, P. (2003). Succession and non-succession concerns of family firms and agency relationships with nonfamily managers. Family Business Review, $16(2), 89-107$.

Clark, P., \& M. Rowlinson. (2004). Treatment of history in organisation studies: Towards an "historic turn”? Business History, 46(3), 331-52.

Clegg, S., Hardy, C., Lawrence, T. B., \& Nord, W. R. (2006). The SAGE handbook of organization studies, $2^{\text {nd }}$ ed., London: SAGE.

Colli, A. (2012). Contextualizing performances of family firms: The perspective of business history. Family Business Review, 25(3), 243-257. 
Colquitt, J. A., \& Zapata-Phelan, C. P. (2007). Trends in theory building and theory testing: A five-decade study of the Academy of Management Journal. Academy of Management Journal, 50(6), 1281-1303.

Congdon, L. (1973). Nietzsche, Heidegger, and history. Journal of European Studies, 3(3), 211-217.

Cope, J. (2005). Researching entrepreneurship through phenomenological inquiry: philosophical and methodological issues. International Small Business Journal, 23(2), $163-189$.

Corriere della Sera. (2009, October 13). Il Padre del Caffè Hag, scomparso senza il suo impero [The father of Hag Coffee, who passed away without his empire]. Retrieved from http://archiviostorico.corriere.it/2009/ottobre/13/padre_del_caffe_Hag_morto_co_9_0910 13110.shtml.

Cyert, R. M., \& March, J. G. (1963). A behavioral theory of the firm. Englewood Cliffs, NJ: Prentice-Hall.

Czarniawska, B. (1997). Narrating the organization: Dramas of institutional identity. Chicago: University of Chicago Press.

Czarniawska, B. (1998). Narrative approach in organization studies. Thousand Oaks, Calif.: Sage Publications.

Czarniawska, B. (1999). Writing management: Organization theory as a literary genre. Oxford; New York: Oxford University Press.

Czarniawska, B. (2004). Narratives in social science research. London: SAGE.

Czarniawska, B. (2010). The uses of narratology in social and policy studies. Critical Policy Studies, 4(1), 58-76.

Czarniawska-Joerges, B., \& Jacobsson, B. (1995). Politics as Commedia dell'Arte. Organization Studies, 16(3), 375-394.

Danto, A. (1991). Narrative and style. The Journal of Aesthetics and Art Criticism, 49(3), 201-209.

Dawson, A. \& Hjorth, D. (2012). Advancing family business research through narrative analysis. Family Business Review, 25(3), 339-355.

de Certeau, M. (1984). The practice of everyday life. Berkeley. CA.: University of California Press.

de Certeau, M. (1997) Heterologies - Discourse on the Other, Minneapolis: University of Minnesota Press. 
Dean, M. (2003). Critical and effective histories - Foucault's methods and historical sociology. London: Routledge.

Deleuze, G. (1988). Spinoza - Practical philosophy, San Francisco: City Lights Books.

Deleuze, G. (2006). Nietzsche and philosophy, transl. by Hugh Tomlinson. New York: Columbia University Press.

Deleuze, G., \& Guattari, F. (1987). A thousand plateaus - Capitalism and schizophrenia, transl. by B. Massumi. Minneapolis: University of Minnesota Press.

De Massis, A., Chua, J. H., \& Chrisman J. J. (2008). Factors preventing intra-family succession. Family Business Review, 21(2), 183-199.

Denison, D., Lief, C., \& Ward, J. L. (2004). Culture in family-owned enterprises: recognizing and leveraging unique strengths. Family Business Review, 17(1), 61-70,

Denzin, N. K., \& Lincoln, Y. S. (Eds.) (1994). Handbook of qualitative research. Thousand Oaks, CA: Sage.

Derrida, J. (1992). Given time: I counterfeit money, transl. by Peggy Kamuf. Chicago: University of Chicago Press.

DiMaggio, P. J. (1988). Interest and agency in institutional theory. Institutional patterns and organizations: Culture and environment, 1, 3-22.

DiMaggio, P. J., \& Powell, W. W. (1983). The iron cage revisited: Institutional isomorphism and collective rationality in organizational fields. American Sociological Review, 48(2), 147-160.

DiMaggio, P., \& Powell, W. (1991). The new institutionalism and organization theory. Chicago: University of Chicago Press.

Editors (2010). Path dependence and path creation: Alternative theoretical and methodological perspectives on strategy, innovation and entrepreneurship. Journal of Management Studies, 47(4), 733-735.

Faccio, M., \& Lang, L. H. P. (2002). The ultimate ownership of Western European corporations. Journal of Financial Economics, 65(3), 365-395.

Family Firm Institute (2013). Family Firm Institute Inc. Retrieved from www.ffi.org (accessed Oct. 21 2013 ).

Feldman, M. S., Sköldberg, K., Brown, R. N., \& Horner, D. (2004). Making sense of stories: A rhetorical approach to narrative analysis. Journal of Public Administration Research and Theory, 14(2), 147-170. 
Fletcher, D. E. (2007). 'Toy Story': the narrative world of entrepreneurship and the creation of interpretive communities. Journal of Business Venturing, 22(5), 649-672.

Foucault, M. (1977). Nietzsche, genealogy, history. In D. F. Bouchard (Ed.), Language, counter-memory, practice: Selected essays and interviews (pp. 139-164). New York: Cornell University Press.

Foucault, M., \& Deleuze, G. (1972/1977). Intellectuals and power, (a conversation between Michel Foucault and Gilled Deleuze), in D. F. Bouchard (Ed.) Language, countermemory, practice: selected essays and interviews with Michel Foucault (pp. 205-217). New York: Cornell University Press.

Fox, M., Nilakant, V., \& Hamilton, R. T. (1996). Managing succession in family owned Businesses. International Small Business Journal, 15(1), 15-25.

Franzosi, R. (1998). Narrative analysis, or why (and how) sociologists should be interested in narrative. Annual Review of Sociology, 24, 517-54.

Frost, P. (Ed.) (1985). Organizational culture. Beverly Hills: SAGE.

Gallagher, C., \& Greenblatt, S. (2000). Practicing new historicism. Chicago: University of Chicago Press.

Gartner, W. B. (2007). Entrepreneurial narrative and a science of the imagination. Journal of Business Venturing, 22(5), 613-627.

Gatens, M. (1996). Imaginary bodies, London: Routledge.

Gedajlovic, E., Carney, M., Chrisman, J. J., \& Kellermanns, F. W. (2012). The adolescence of family firm research: Taking stock and planning for the future. Journal of Management, 38(4), 1010-1037.

Geertz, C. (1973). The interpretation of cultures. London: Fontana Press.

Georgakopoulou, A. (2003). Plotting the 'right place' and the 'right time': Place and time as interactional resources in narratives. Narrative Inquiry, 13(2), 413-432.

Gersick, K. E., Davis, J. A., Hampton, M. M., \& Lansberg, I. (1997). Generation to generation: Life cycles of the family business. Harvard Business School Press, Cambridge, MA.

Greenblatt, S. (1984). Renaissance self-fashioning - from More to Shakespeare. Chicago and London: The University of Chicago Press.

Greenblatt, S. (1990). Learning to curse: Essays in early modern culture. New York and London: Routledge.

Greenblatt, S. (1997). The Touch of the real. Representations, 59, 14-29.

Grosz, E. (1994). Volatile bodies: Toward a corporeal feminism. Bloomington: Indiana 
University Press.

Grote, J. (2003). Conflicting generations: A new theory of family business rivalry. Family Business Review, 16(2), 113-122.

Handler, W. C. (1994). Succession in family business: A review of the research. Family Business Review, 7(2), 133-157.

Hargadon, A. B., \& Douglas, Y. (2001). When innovations meet institutions: Edison and the design of electric light, Administrative Science Quarterly, 46(3), 476-501.

Heugens, P. P., \& Lander, M. W. (2009). Structure! Agency! (and other quarrels): A metaanalysis of institutional theories of organization. The Academy of Management Journal, $52(1), 61-85$.

Hirshleifer, J. (1977). Shakespeare vs. Becker on altruism: The importance of having the last word. Journal of Economic Literature, 15(2), 500-502.

Hjorth, D. (2004). Towards genealogic storytelling in entrepreneurship, in D. Hjorth \& C. Steyaert (Eds.) Narrative and discursive approaches in entrepreneurship. Cheltenham: Edward Elgar.

Hjorth, D. (2007). Lessons from Iago: Narrating the event of entrepreneurship. Journal of Business Venturing, 22(5), 712-732.

Hjorth, D., \& Steyaert, C. (Eds.) (2004). Narrative and discursive approaches in entrepreneurship. Cheltenham: Edward Elgar.

Hosking, D. M., \& Hjorth, D. (2004). Relational constructionism and entrepreneurship: some key notes, in D. Hjorth \& C. Steyaert (Eds.) Narrative and discursive approaches in entrepreneurship (pp. 255-268). Cheltenham: Edward Elgar.

Hubler, T. (1999). Ten most prevalent obstacles to family-business succession planning. Family Business Review, 12(2), 117-121.

Jennings, P., Perren, L., \& Carter, S. (2005). Guest editors' introduction: Alternative perspectives on entrepreneurship research. Entrepreneurship Theory and Practice, 29(2), $145-152$.

Kertzer, D. L. (1983). Generation as a sociological problem. Annual Review of Sociology, 9, $125-149$.

Keulen, S., \& Kroeze, R. (2012). Understanding management gurus and historical narratives: The benefit of a historic turn in management and organization studies. Management $\&$ Organizational History, 7(2), 171-189.

Knapp, S. (1989) Collective memory and the actual past. Representations, 26(Spring), 123149. 
Knight, G. W. (2001). The wheel of fire: Interpretations of Shakespearian tragedy. London: Routledge.

Kondra, A. Z., \& Hinings, C. R. (1998). Organizational diversity and change in institutional theory. Organization Studies, 19(5), 743-767.

Kuhn, T. (1962). The structure of scientific revolutions. Chicago: The University of Chicago Press.

Lam, W. (2011). Dancing to two tunes: Multi-entity roles in the family business succession process. International Small Business Journal, 29(5), 508-533.

La Porta, R., Lopez-de-Silanes, F., \& Shleifer, A. (1999). Corporate ownership around the world. Journal of Finance, 54(2), 471-517.

Latour, B. (1987) Science in action: How to follow scientists and engineers through society, Cambridge: Harvard University Press.

Le Breton-Miller, I., Miller, D., \& Steier, L. (2004).Toward an integrative model of effective FOB succession. Entrepreneurship Theory and Practice, 28(4), 305-328.

Lee, J. (2006). Impact of family relationships on attitudes of second generation in family business. Family Business Review, 19(3), 175-191.

Leitch, C. M., Hill, F. M., \& Harrison, R. T. (2010). The philosophy and practice of interpretivist research in entrepreneurship: Quality, validation, and trust. Organizational Research Methods, 13(1), 67-84.

Litz, R. A., Pearson, A. W., \& Litchfield, S. (2012). Charting the future of family business research: Perspectives from the field. Family Business Review, 25(1), 16-32.

Lorenz, C. (2011). History and theory. In A. Schneider, D. Woolf, \& I. Hesketh (Eds.), The Oxford history of historical writing, Vol. 5: Historical Writing Since 1945 (pp. 13-35). Oxford: Oxford University Press.

Lyotard, J-F. (1984). The postmodern condition: A report on knowledge. Manchester: Manchester University Press.

MacIntyre, A. (2007). After virtue (3rd ed.). Notre Dame: University of Notre Dame Press. Mannheim, K. (1952). The sociological problem of generations. Essays on the Sociology of Knowledge, 276-322.

Massumi, B. (2011). Semblance and event: Activist philosophy and the occurrent arts. MIT press.

McDonald, T. J. (Ed.). (1996). The historic turn in the human sciences. Ann Arbor: University of Michigan Press. 
Meyer, J. W., \& Rowan, B. (1977). Institutionalized organizations: Formal structure as myth and ceremony. American Journal of Sociology, 83(2), 340-363.

Nava, M-T., Rania, L., \& Ramona K. Z. (2014) Family toward the cluster model: The family firm's entrepreneurial behavior over generations. Family Business Review, 27(2), 161185.

Nietzsche, F. (1989). On the genealogy of morals, transl. by W. Kaufmann, \& R. Hollingdale. New York: Vintage Books.

Nietzsche, F. (1997). Untimely meditations. New York: Cambridge University Press.

Nietzsche, F. (2005). Thus spoke Zarathustra, transl. by Graham Parkes. Oxford: Oxford World's Classics.

O’Connor, E. S. (1995). Paradoxes of participation: Textual analysis and organizational Change. Organization Studies, 16(5), 769-803.

O'Connor, E. S. (2004). Storytelling to be real: narrative, legitimacy building and venturing. In D. Hjorth \& C. Steyaert, C. (Eds.) Narrative and discursive approaches in entrepreneurship (pp. 105-124). Cheltenham: Edward Elgar.

O’Sullivan, M., \& Graham, M. B. W. (2010). Moving forward by looking backward:

Business history and management studies. Journal of Management Studies, 47(5), 775790.

Owen, D. (2007). Nietzsche's genealogy of morality. London: Acumen Press.

Paavola, S., \& Hakkarainen, K. (2005). Three abductive solutions to the meno paradox With instinct, inference, and distributed cognition. Studies in Philosophy and Education, $24(3-4), 235-253$.

Parker, M. (2011). Organizing the circus: The engineering of miracles. Organization Studies, 32(4), 555-569.

Philips, N., Lawrence, P. N., \& Hardy, C. (2004). Discourse and institutions. Academy of Management Review, 29(4), 635-652.

Pilcher, J. (1994). Mannheim's sociology of generations: An undervalued legacy. British Journal of Sociology, 45(3), 481-495.

Polkinghorne, D. E. (1988). Narrative knowing and the human sciences. New York: SUNY. Popp, A., \& Holt, R. (2013a). Entrepreneurship and the organization of being: the case of the Shaws. Entrepreneurship and Regional Development, 25(1-2), 52-68.

Popp, A., \& Holt, R. (2013b). The presence of entrepreneurial opportunity. Business History, 55(1), 9-18. 
Powell, W. W., \& DiMaggio, P. J. (1991). The new institutionalism in organisational analysis. Chicago: University of Chicago Press.

Rescher, N. (1996). Process metaphysics: An introduction to process philosophy. New York: SUNY Press.

Rhodes, C. (2009). After reflexivity: Ethics, freedom and the writing of organization studies. Organization Studies, 30(6), 653-672.

Ricoeur, P. (2004). Memory, history, forgetting, transl. by K. Blamey, \& D. Pellauer. Chicago: University of Chicago Press

Rowlinson, M., Booth, C., Clark, P., Delahaye, A., \& Procter, S. (2010). Social remembering and organizational memory. Organization Studies, 31(1), 69-87.

Rowlinson, M., Hassard, J., \& Decker, S. (2014). Strategies for organizational history: A dialogue between historical theory and organization theory. Academy of Management Review, 39(3), 250-274.

Rowlinson, M., \& Procter, S. (1999). Organizational culture and business history. Organization Studies, 20(3), 369-396.

Sahlins, M. (2004). Apologies to Thucydides: Understanding history as culture and vice versa. Chicago: University of Chicago Press.

Scharff, R. C. (1997). Heidegger's ‘appropriation' of Dilthey before being and time. Journal of the History of Philosophy, 35(1), 105-128.

Schreyögg, G. and Sydow, J. (2011). Organizational path dependence: A process view. Organization Studies, 32(3), 321-335.

Schulze, W. S., Lubatkin, M. H., \& Dino, R. N. (2001). Agency relationships in family firms: Theory and evidence. Organization Science, 12(2), 99-116.

Schutz, A. (1964). Collected papers II: Studies in social theory (A. Brodersen, Ed.). The Hague: Martinus Nijhoff.

Scott, R. W. (1987). The adolescence of institutional theory. Administrative Science Quarterly, 32(4), 493-511.

Shakespeare, W. (1968). King Lear. (G. I. Duthie, \& J. D. Wilson, Eds.). London: Cambridge University Press.

Shapiro, G. (1989). Nietzschean narratives. Bloomington: Indiana University Press.

Sharma, P. (2004). An overview of the field of family business studies: Current status and directions for the future. Family Business Review, 17(1), 1-36. 
Sharma, P., Chrisman, J. J., \& Chua, J.H. (Eds.) (1996). A review and annotated bibliography of family business studies. Assinippi Park: Kluwer Academic Publishers.

Sinclair, M. (2004). Nietzsche and the problem of history. Richmond Journal of Philosophy, 8(Winter), 1-6.

Smircich, L. (1983). Concepts of culture and organizational analysis, Administrative Science Quarterly, 28(3), 339-358.

Smircich, L., \& Morgan, G. (1982). Leadership: The management of meaning. Journal of Applied Behavioural Science, 18(2), 257-273.

Smith, R., \& Anderson, A. R. (2004). The devil is in the e-tale: Forms and structures in the entrepreneurial narratives. In D. Hjorth, \& C. Steyaert (Eds.) Narrative and discursive approaches in entrepreneurship (pp. 125-143). Northampton, MA: Edward Elgar Publishing.

Söder, H-P. (2003). The return of cultural history? 'Literary' historiography from Nietzsche to Hayden White. History of European Ideas, 29(1), 73-84.

Spivak, G. C. (1990). The post-colonial critic: Interviews, strategies, dialogues, Sarah Harasym (Ed.). London: Routledge.

Stengers, I. (2000). The invention of modern science. Minneapolis: The University of Minnesota Press.

Stone, A. (2005). Essentialism and anti-essentialism in feminist philosophy. Journal of Moral Philosophy, 1(2), 135-153.

Tagiuri, R., \& Davis, J. A. (1996). Bivalent attributes of the family firm. Family Business Review, 9(2), 199-208.

Tatoglu, E., Kula, V., \& Glaister, K. W. (2008). Succession planning in family-owned businesses: Evidence from Turkey. International Small Business Journal, 26(2), 155180.

Üsdiken, B., \& Kieser, A. (2004). Introduction: History in organisation studies. Business History, 46(3), 321-330.

Wadhwani, R. D., \& Bucheli, M. 2014. The future of the past in management and organizational studies. In M. Bucheli, \& R. D. Wadhwani (Eds.), Organizations in time: History, theory, methods (pp. 3-31). New York: Oxford University Press.

White, H. (1973) Metahistory: The Historical Imagination in Nineteenth-Century Europe. Baltimore: The Johns Hopkins University Press. 1973.

White, H. (1974/1978). The historical text as literary artifact. Clio, 3(3), 277-303. Republished (1978) in Tropics of discourse - Essays in cultural criticism (pp. 81-100). 
Baltimore/London: Hopkins University Press.

White, H. (1978). Tropics of Discourse - Essays in Cultural Criticism. Baltimore/London: John Hopkins University Press.

White, H. (1984). The question of narrative in contemporary historical theory. History and Theory, 23(2), 1-33.

White, H. (2005). Introduction: Historical fiction, fictional history, and historical reality. Rethinking History, 9(2/3), 147-157.

Williams, M. (2000). Interpretivism and generalisation. Sociology, 34(2), 209-224.

Willmott, H. (1984). Images and ideals of managerial work: A Critical examination of conceptual and empirical accounts. Journal of Management Studies, 21(3), 349-368.

Winch, P. (1958). The idea of a social science and its relation to philosophy. London: Routledge.

Winnicott, D. W. (1971). Playing and reality. London: Tavistock.

Zerubavel, E. (1996) Social Memories: Steps to a Sociology of the Past, Qualitative Sociology, 19(39), 283-299. 
Table I. Burke's Pentad Applied to the Empirical Material

\begin{tabular}{|c|c|c|}
\hline $\begin{array}{r}\text { Burke's } \\
\text { Pentad }\end{array}$ & Berger sr.'s autobiography & King Lear \\
\hline Act & $\begin{array}{l}45 \text { years of Berger's life, in which he } \\
\text { escapes poverty to create a business } \\
\text { empire; deciding to leave his wealth to } \\
\text { the next generation }\end{array}$ & $\begin{array}{l}\text { Transferring wealth and status to the next } \\
\text { generation; measuring his daughters' love for } \\
\text { him }\end{array}$ \\
\hline Agents & $\begin{array}{l}\text { Berger and his son; other children; } \\
\text { business/legal advisers }\end{array}$ & $\begin{array}{l}\text { The Dramatis Personae of Shakespeare's play } \\
\text { (primarily Lear; those who love him: Cordelia, } \\
\text { The Fool, Albany, Kent, Gloucester, and Edgar; } \\
\text { and those hate and fear him: Goneril, Regan, } \\
\text { Cornwall, and Oswald; the great villain Edmund) }\end{array}$ \\
\hline Agency & $\begin{array}{l}\text { Berger uses his entrepreneurial skills to } \\
\text { build a business empire; he creates a } \\
\text { legal trust when he retires; his children } \\
\text { "conspire" to exclude him from the } \\
\text { trust }\end{array}$ & $\begin{array}{l}\text { Immensely complex (Shakespearean style) but an } \\
\text { attempted act of altruism by Lear, weaved into a } \\
\text { petty craving for weighing love }\end{array}$ \\
\hline Scene & $\begin{array}{l}\text { Jewish family escaping persecution; } \\
\text { Modern-day Italy (including the "Clean } \\
\text { Hands" investigation, a series of bribery } \\
\text { scandals involving politics and } \\
\text { business) }\end{array}$ & $\begin{array}{l}\text { Perhaps most correctly stated as Lear's Kingdom } \\
\text { and all the web of relations that have invested in } \\
\text { its present and future }\end{array}$ \\
\hline Purpose & $\begin{array}{l}\text { Provide for future generations; } \\
\text { autobiography written for social } \\
\text { promotion of entrepreneurship and its } \\
\text { values }\end{array}$ & $\begin{array}{l}\text { Lear's purpose is perhaps to find out how much his } \\
\text { daughters love him, or to somehow fabricate a } \\
\text { proof that he is loved }\end{array}$ \\
\hline
\end{tabular}

